\title{
THE ROLE OF COMMON ORCHIDS IN APPRECIATING THE COMPLEXITY OF BIODIVERSITY CONSERVATION
}

\author{
Marilyn H. S. Light* \& Michael MacConaill \\ 174, rue Jolicoeur, Gatineau, QC J8Z 1C9, Canada \\ *Corresponding author: mlight@igs.net
}

ABSTRACT. To conserve a species, we must understand its biology, ecology, and relative vulnerability to change. To conserve biodiversity, we need a profound understanding of the relative impact of natural and anthropogenic disturbances and species interactions and of the role of the ecosystem in species survival. Assumptions of the basis for abundance and decline and therefore conservation status might be ill founded if we miss critical aspects of life history or of inter-relationships with other organisms. For more than two decades we have monitored populations of two common terrestrial orchids that grow in close proximity in Gatineau Park, Québec, Canada. The relative abundance and availability of large populations of Cypripedium parviflorum var. pubescens and of the introduced Epipactis helleborine presented us with an opportunity to conduct in situ experimentation, and to develop and evaluate conservation approaches not possible with uncommon or rare orchids. We have learned that the distribution, patchiness, and persistence of E. helleborine is related to the presence and diversity of trees and that seeds of this orchid in trampled soil may germinate better than those in undisturbed soil but that location is a likely overriding variable. Experimental trampling within colonies of common orchids has revealed that the fungivorous nematode community is negatively impacted by foot traffic, which could be reflecting subtle changes in the soil fungal assemblage upon which the nematodes feed. While mature plants of C. parviflorum var. pubescens do not seem to have been affected by nearby foot traffic, seed germination and seedling survival could have been altered, but we may not become aware of such changes for some time.

Resumen. Para conservar especies se debe comprender su biología, ecología y su relativa vulnerabilidad a cambios. Para conservar la biodiversidad, necesitamos un entendimiento profundo del impacto de los disturbios naturales y antropogénicos, de las interacciones y, del rol que juega el ecosistema en la supervivencia de las especies. Las suposiciones de abundancia y declinación y por consiguiente el estatus de conservación puede ser totalmente erróneo si no se toman en cuenta aspectos críticos de la historia natural o las relaciones con otros organismos. Por más de dos décadas hemos monitoreado las poblaciones de dos orquídeas terrestres que crecen en la cercanía del Parque Gatineau, Québec, Canadá. La abundancia relativa y disponibilidad de poblaciones grandes de Cypripedium parviflorum var. pubescens y de la especie introducida Epipactis helleborine nos dio la oportunidad de realizar experimentos in situ y de desarrollar y evaluar aspectos de conservación los cuales no son ejecutables con orquídeas poco comunes o raras. Hemos aprendido que la distribución, congregación y persistencia de E. helleborine está relacionada con la de diversidad de árboles y también que las semillas de las orquídeas germinan mejor en tierra apisonada que en aquella que no presenta disturbio, sin embargo, la localidad sería una variable preponderante. Apisonamiento experimental ocasionado por el tráfico de transeúntes dentro de las localidades de colonias de orquídeas comunes ha revelado un impacto negativo en las comunidades de nemátodos fungívoros, lo que podría reflejar ligeros cambios en el ensamblaje fúngico del cual los nemátodos se alimentan. Entre tanto, las plantas maduras de C. parviflorum var. pubescens no parecen ser afectadas por los efectos que tienen los transeúntes en el sendero. Sin embargo, la germinación y la supervivencia de las plántulas podrían haber sido alteradas, pero no nos daremos cuenta de estos cambios en algún tiempo.

KeY WORDS: Orchidaceae, conservation, disturbance, trampling, Cypripedium parviflorum var. pubescens, Epipactis helleborine 
When we first considered monitoring terrestrial orchid populations in Gatineau Park, Québec, Canada, one of our concerns was the potential impact of our visits on rare or uncommon species and their habitats. We chose instead to monitor populations of two very common orchids, Cypripedium parviflorum var. pubescens (Willd.) O.W.Knight and the introduced European orchid, Epipactis helleborine (L.) Crantz. Not only were there large populations consisting of hundreds of individuals but there was the additional possibility to conduct in situ experimentation which might not have been possible with rare species and certainly not on a large scale. We felt that our observations might be of future benefit to conservationists working with rare taxa where the outcome of interventions can be fraught with uncertainty. To minimize impact on orchid habitat, we followed a set path within sites and limited the number of visits to the minimum needed to obtain data. Despite these precautions, we realized that there would be some disturbance (however minimal) and that annual monitoring could have an unpredictable impact on orchid survival in the research sites. We wondered how we could assess our physical impact on things we could not see or predict and what measures could be undertaken to mitigate further monitoring impact on the orchid ecosystem. In 2006, we began a study to quantify visitor impact on orchid habitat. Cypripedium parviflorum var. pubescens was selected for this study because it was shallow-rooted and therefore potentially more vulnerable to trampling (Light \& MacConaill, 2007). We employed a daily 5 -minute standing visit in pre-set locations for 10 days during the orchid blooming season to simulate a typical observer visit. Trampling spots were located where one might stand to count flowers or take photographs, or within 50 $\mathrm{cm}$ of a flowering plant. We wanted to quantify soil compaction, characterize the impact of trampling on soil organisms, and track recovery from trampling. Soil nematodes were selected as a bioindicator because they have been demonstrated to be an excellent indicator of soil health and can also be easily extracted and identified to trophic or feeding group based upon mouth and gut structure (Neher, 2001). This first study, with follow-up measurements during 2007, demonstrated that 10 daily standing visits compacted soil and perturbed the nematode community. These changes were still significantly different from controls after 16 months (Light \& MacConaill, 2007, 2008). We needed to learn how long the trampling effect of this first experiment would endure, if the results could be repeated in different habitats, and if trampling modified orchid seed germination behavior. We decided to use the seeds of E. helleborine instead of the Cypripedium for this first assessment of trampling impact on seed germination because we already had conducted a preliminary study of in situ germination of E. helleborine.

\section{Materials and methods}

Effects of visitor trampling on a terrestrial orchid habitat - In 2008, the earlier trampling experiment (Light \& MacConaill, 2007) was repeated in three nearby yet different sites in Gatineau Park, Québec, Canada, that had the following characteristics. Site A was a long-term study site located in open forest (Light \& MacConaill, 2002 a,b): clay soil, pH 6.4 (range: 5.8 -7.0: n=15); dominant trees, Acer saccharum Marshall and Quercus rubra L.; orchid, Cypripedium parviflorum var. pubescens. Test and control plots were placed near previously mapped orchid plants with foot-traffic history (plots were located where no visitor traffic was likely to have occurred over the past 10 years). Site $\mathrm{S}$ was an isolated forest clearing located about $150 \mathrm{~m}$ to the south of A: clay soil, $\mathrm{pH} 6.4$ (range: 6.1- 6.8: $\mathrm{n}=15$ ); dominant tree, Acer saccharum; orchid, C. parviflorum var. pubescens. Site $\mathrm{H}$ was a small valley located about $50 \mathrm{~m}$ to the north of Site A featuring a centrally located game trail: humus soil with low clay content, $\mathrm{pH}$ 6.5: range, 6.1-6.8, $\mathrm{n}=15$; dominant trees, Quercus rubra, Pinus strobus L., and Acer saccharum. Site H had previously supported a small population of Platanthera hookeri (Torr.) Lindl. We established experimental plots along either side of the valley off the game trail and away from these orchids.

Experimental trampling consisted of a 5-minute standing visit daily for 10 consecutive days during the flowering period of $C$. parviflorum var pubescens in May. Soil compaction and temperature were assessed daily for a total of 30 days before, during, and after the experimental trampling period, and monthly thereafter until September. A pocket penetrometer (Cole-Palmer) was used to measure resistance to penetration of the soil by a standard cylinder. The nematode community 
composition of all experimental plots and the associated research trails was assessed as previously described (Light \& MacConaill, 2007), with paired soil cores $(5.5 \mathrm{~cm}$ dia $\times 3 \mathrm{~cm}$ deep) being taken from a randomly selected footprint in each sample plot in the first year and from the opposite footprint in the second year. Insufficient area remained for coring of footprints in the third year (2008), although sufficient footprint surface was still present for the compaction measurements in those plots.

Distribution and association of Epipactis helleborine with large trees-Epipactis helleborine is locally common in Gatineau Park where we have extensive knowledge of its biology and distribution in our longterm study Site 1. It was in this site that we noticed a clear association with a large tree, $44 \mathrm{~cm}$ diameter at breast height (dbh), rather than with any of the 31 much smaller trees and saplings (1 to $11.5 \mathrm{~cm} \mathrm{dbh}$ ) that shared the site (Light \& MacConaill, 2006a). The 15 largest trees in an area of open forest adjacent to this site were identified and mapped during the autumn of 2005 (Fig. 1). These trees were 15 to $20 \mathrm{~m}$ tall and ranged in diameter (dbh) from 17 to $75 \mathrm{~cm}$ with a median value of $45 \mathrm{~cm}$. The scattered smaller trees and saplings in this area were mainly Ostrya virginiana (Mill.) K.Koch. All E. helleborine plants emerging during 2006 within a $3 \mathrm{~m}$ radius from the trunk of each of the 15 large trees (total area approx. $445 \mathrm{~m} 2$ ) were counted and mapped. For the purpose of comparison, we surveyed a similar-sized, sparsely forested area outside those circles (Fig. 1). All orchids emerging in this area were counted and mapped. Trampling during this survey was minimized by walking whenever possible on exposed rocks and by keeping to an established assessment trail. Plant densities in selected areas were compared by calculating the $X 2$ statistic (Sokal \& Rohlf, 1981) for the differences between the observed numbers in those areas and the numbers expected from the null hypothesis of a uniform distribution across the total relevant area.

Impact of trampling on germination of Epipactis helleborine-We used our knowledge of E. helleborine distribution from the 2006 survey to place seed packets where we expected to obtain the most useful results: where orchids were growing and mycorrhizal fungi were likely present, within $5 \mathrm{~m}$ of a large tree. Mature

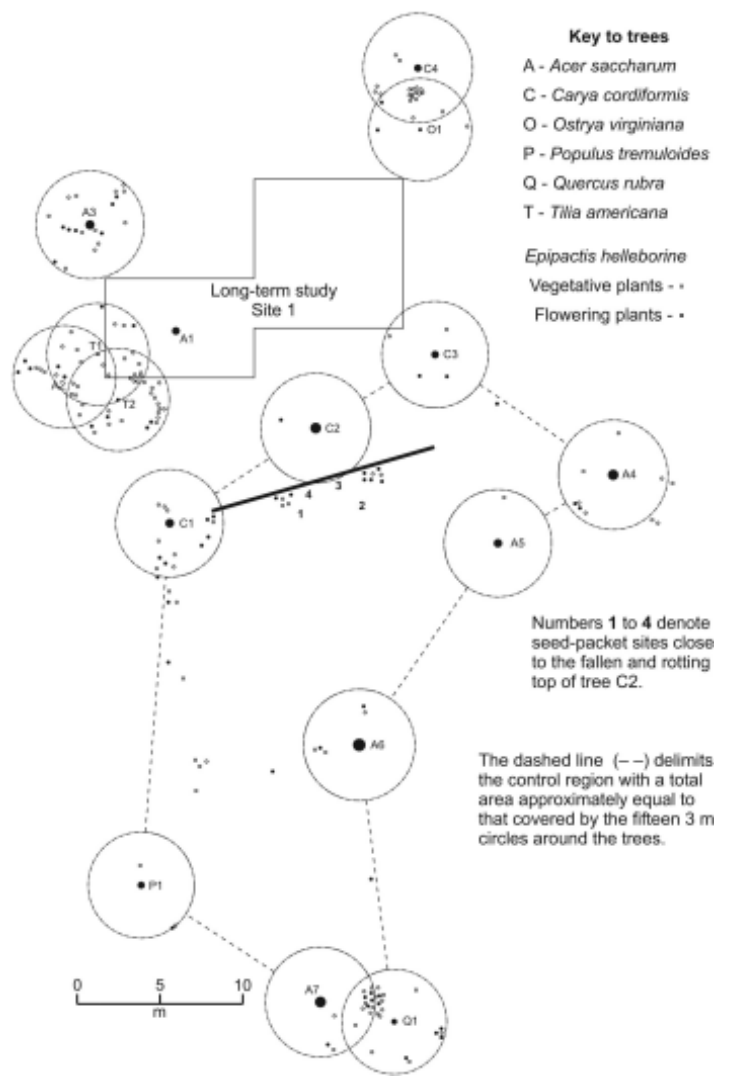

Figure 1. Location of 15 large trees, vegetative and flowering E. helleborine found in 2006, and seed packet burials (1 to 4) within $5 \mathrm{~m}$ of a dead Carya cordiformis (C2) and its fallen treetop (solid line). Trees are circumscribed by $3 \mathrm{~m}$ radius circles.

fruits were harvested at the time of dehiscence from large plants growing in the same general vicinity as the experiment. Seeds were dried and stored at room temperature for 60 days over silica gel until the day before preparation and placement of seed packets (November 1, 2006). Seed packets were constructed of fine nylon mesh enclosed in $35 \mathrm{~mm}$ plastic slide mounts. Approximately 150 to 200 seeds were placed in each packet and the mounts stapled at three points. A small hole was punched through one corner of a mount through which a length of nylon fishing line was fastened. All packets could thus be tethered to a central plastic peg to simplify retrieval. Four groupings of 3 packet-pairs per plot (24 seed packets in all) were buried within 5 m of a large tree, Carya cordiformis (Wangenh.) K.Koch, that had died after a 1998 storm had broken 
the treetop (Fig. $1-\mathrm{C} 2$ ). The fallen treetop log formed the upper boundary of packet burials (Fig. 1). Pairs of tethered seed packets were buried in groups of 3 with pairs arranged at 120-degree intervals around a central peg. Two groups were sited $1 \mathrm{~m}$ apart and about $50 \mathrm{~cm}$ from the log. The two other groups were sited about 1 $\mathrm{m}$ apart and away from the others. The packet groups were located between the two clusters of $E$. helleborine plants that had emerged in 2006 (Fig. 1). To minimize soil disturbance during packet placement, a stout knife was used to cut slots in the soil into which packets were placed horizontally about $5 \mathrm{~cm}$ beneath the surface. For each group of 3 packet-pairs, two pairs were randomly chosen for trampling at a rate of 30 footsteps per packet (16 packets trampled in all). Controls were untrampled. Soil resistance to penetration was assessed before and after packet placement and two years later just before the packets were removed (November 2008). Packets were washed, opened and scored for germination and seedling development (Stage 1 - swollen embryo-testa not split; Stage 2 - swollen embryo-testa split; Stage 3 - protocorm with rhizoids; Stage 4+ - protocorm with $\operatorname{root}(\mathrm{s})$.

\section{Results}

Follow up of the 2006 study - Residual soil compaction still persisted 28 months after the initial 2006 study (Fig. 2). Soil compaction measurements still tracked with soil temperature (Fig. 2), with resistance to penetration increasing and decreasing concomitantly with soil temperature. Both trampled and untrampled soils behaved similarly. Because we had already removed four cores from each pair of footprints, there was insufficient surface area remaining for core sampling of trampled plots in the third year. There was, however, sufficient trampled surface remaining to measure residual compaction.

Effects of trampling in different habitats-The results were essentially the same at each of the 3 sites. Soil compaction increased with each trampling episode during the 10- day experimental period and remained significantly higher than controls in each of the sites for the four months after experimental trampling until the experiment was terminated (Fig. 3). Heavy rainfall on two occasions induced a brief soil softening before recovery.

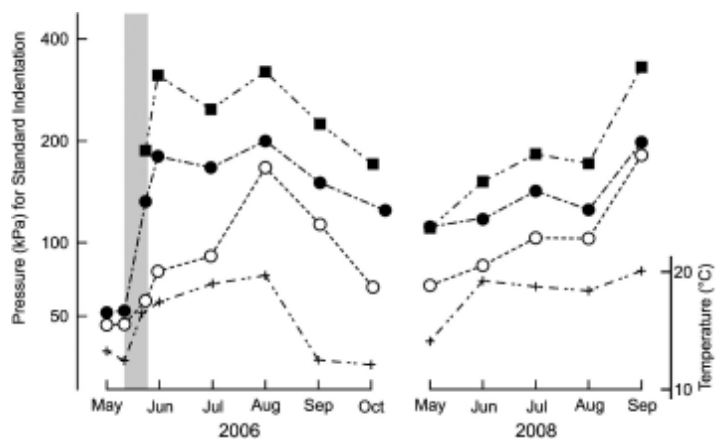

FIgURE 2. Soil compaction recovery over 28 months following 10 days of daily 5-minute standing visits in May 2006 (2007 data omitted for brevity). Control values, open circles; trampled plots, filled circles; research trails, filled squares. Trampling period shown by gray bar. Soil temperature shown by crosses.

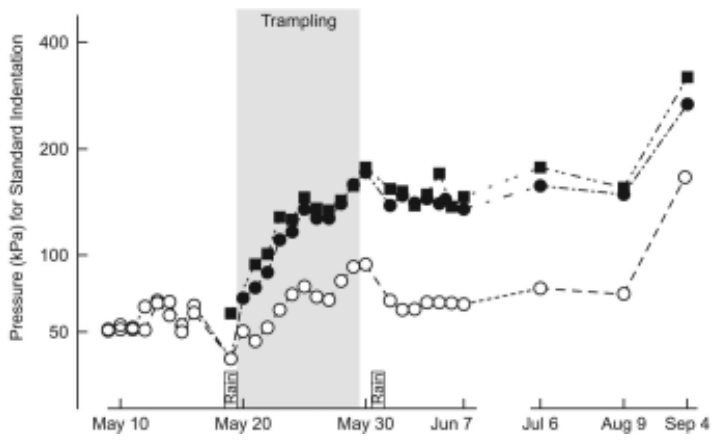

Figure 3. Soil compaction assessment over 4 mo in 3 sites (A, H, S - pooled) before, during, and monthly thereafter following daily 5-min standing visits for 10 days in May 2008 (gray vertical band). Heavy rain days are indicated - Rain. Control values, open circles; trampled plots, filled circles; research trails, filled squares.

Soil nematode assemblages, although different in composition at each site, were similarly impacted by trampling. The experimental trampling and trail samples showed a significantly lower proportion of fungivorous to total nematodes than control plots, with $8 \%, 10 \%$, and $26 \%$, respectively [Wilcoxon Rank Test: $t=3.23(\mathrm{P}<0.001)]$.

Distribution and association of E. helleborine with large trees-We found 159 E. helleborine plants within $3 \mathrm{~m}$ of the marked trees of which 44 were flowering stems. Twenty-four plants were found outside the $3 \mathrm{~m}$ circles but within the control region: 12 of these plants were flowering. A further 4 plants were observed just outside the $3 \mathrm{~m}$ circles and the control region, one of which 


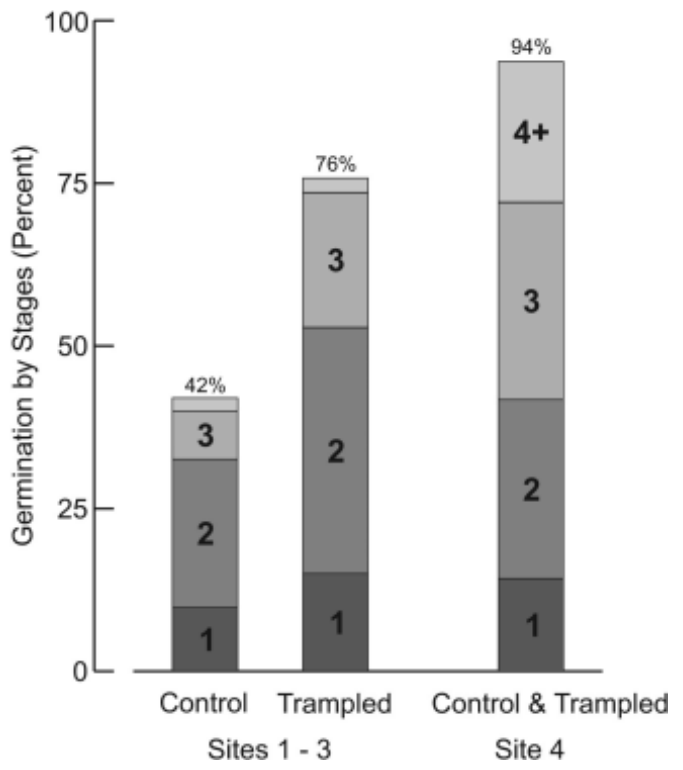

FiguRE 4. Proportional germination and seedling development by stages in packets of E. helleborine seeds buried at $5 \mathrm{~cm}$ depth for 2 years, with and without 30 footsteps immediately after burial.

was flowering (Fig. 1). Two groups of 5 and 7 plants, respectively, were found within $5 \mathrm{~m}$ of Carya cordiformis $\mathrm{C} 2$ and within $1 \mathrm{~m}$ of the fallen top of that tree.

High orchid density was found to be strongly associated with some of the large trees, although there was significant heterogenity $(X 102=90, P<<0.001)$ in the distribution. The greatest density ( 52 plants in 60 m2) was observed in the tree cluster consisting of Acer saccharum $\mathrm{A} 2$ and the two Tilia americana $\mathrm{L}$., the four next densest being locations around Acer A3, Carya cordiformis $\mathrm{C} 1$ and the two pairs of close neighbors, Acer A7 with the Quercus rubra and Carya C4 with the Ostrya virginiana. In the latter two cases, the orchids were concentrated where the $3 \mathrm{~m}$ assessment areas overlapped, with 26 plants in the $15 \mathrm{~m} 2$ overlapping regions and 24 in the remaining outer $98 \mathrm{~m} 2(X 2=$ $65, P<<0.001$ ), and with 9 of the 17 remaining plants associated with the Quercus being within $4 \mathrm{~m}$ of the trunk of the neighboring Acer (Fig.1).

Impact of trampling on germination of $\mathrm{E}$. helleborineThree of four seed packet groupings showed a significant positive effect of trampling on subsequent germination (Fig. 4). With these groupings, germination and seedling development after two years of burialwere greater with trampled packets than with controls. While control and trampled plots had been similarly loosened when packets of seeds were buried, only the trampled plots where the soil was still significantly more compacted after two years showed enhanced germination and development. In the fourth packet grouping, located within $2 \mathrm{~m}$ of the other groups and close to the felled top of the dead Carya cordiformis, being within $4 \mathrm{~m}$ of the trunk of that tree, control and trampled seed packets showed equally high (94\%) germination and enhanced seedling development. We could not separate the results of control and trampled packet behavior in this group.

\section{Discussion}

The use of common plants and animals as models toward the development of ecological and evolutionary theory is not surprising. Many of these model organisms were likely first selected because they were small, common, and easily cultured and propagated (Somerville and Koormeet, 2002). The nematode, Caenorhabditis elegans Maupas, the mustard, Arabidopsis thaliana (L.) Heynyh. and the garden snapdragon, Antirrhinum majus L. have become pivotal to our understanding of how many organisms behave at a genetic and genomic level. Orchids can be used to understand flower development (Johansen and Fredericksen, 2002) while mimetic orchids, which employ deception to attract potential pollinators, have proved to be useful models to investigate the molecular mechanisms of floral mimicry (Schlueter \& Schiestl, 2008).

Conservation of species presents many challenges, and conservation of biodiversity even more. Conservation is typically managed on a by-species basis with an emphasis on vulnerable species or species at risk yet often without an understanding of how similar yet common species behave in response to shared challenges including disturbance and competition. "Commonness is itself rare," according to Gaston and Fuller (2007). There may be more of a single species and that species may be widespread, but there are not that many species that are so common or so widespread even within Orchidaceae. Commonness brings with it a risk of neglect or disinterest (Dixon \& Backhouse, 2007).

One approach to biodiversity conservation is the creation of protected areas where human activities 
can be controlled. Control of visitor movement is not always possible, especially in urban parks or where flowering orchids have become a tourist attraction. In the Mingan Archipelago National Park Reserve of Canada, scientists have been monitoring a population of Cypripedium passerinum Richardson. Their observations have revealed that eight of the 12 colonies were below the minimum plant numbers considered necessary to their survival (Nantel \& Cantin, 1998). Because the impact of monitoring on the fragile habitat was unknown, the investigators recommended monitoring these eight colonies every three years, whereas a five-year interval was considered appropriate to monitor the other four colonies. Perhaps the knowledge of trampling impact on the habitat will assist park managers with a similar challenge. Until we have an understanding of the impact of natural and anthropogenic disturbance on the establishment and survival of orchids, we cannot adequately protect them nor can we begin to address the challenge of ecosystem conservation.

Long-term study of common temperate terrestrial orchids in Gatineau Park, Québec, Canada, has been used to examine how weather affects pollinator activity and germinable seed production of Cypripedium parviflorum var. pubescens (Light \& MacConaill, 2002, 2006b) and also how visitor traffic, including monitoring activities of the shallow-rooted orchid, would impact the terrestrial ecosystem which could ultimately affect the orchids (Light \& MacConaill, 2007, 2008). It is helpful that both E. helleborine and $C$. parviflorum var. pubescens can and do grow in close proximity in Gatineau Park where weather and natural disturbances such as the catastrophic ice storm of January 1998 were shared phenomena yet elicited different responses by these orchids (Light \& MacConaill, 2006b). Where a single C. parviflorum var. pubescens growing within the E. helleborine population of Site 1 was positively affected by the ice storm after a massive litter fall increased the quantity of decaying wood (the plant quadrupled in size over the next 3 years), mature plants of E. helleborine were not similarly affected (Light \& MacConaill, 2002). Indeed, the earlier natural death of a large tree in the same part of Site 1 and subsequent drought was suggested as a reason for the decline of plant numbers near that tree, whereas the presence of another healthy large tree about $10 \mathrm{~m}$ away was suggested as the reason why some $E$. helleborine were able to survive within $3 \mathrm{~m}$ of that tree to re-emerge after 17 years (Light \& MacConaill, 2006a,b). The association of emergent E. helleborine in 2006 with certain species of large trees is therefore not surprising and underscores the importance of such large trees to this common orchid. The exceptional concentration of orchids between tree pairs and with the 3-tree grouping warrants further investigation.

Despite the seeming weediness of this introduced orchid in North America, seeds do not germinate and grow everywhere they are placed. Our previous experience with experimental in situ seed germination (unpublished data) guided the placement of seed packets in the present study. Others working with rare or uncommon species of Epipactis Zinn, Cephalanthera Rich., and other orchids known to form mycorrhizal associations with trees might find our observations useful.

Our experiment on the impact of trampling on buried seeds of $E$. helleborine has revealed that trampling affected germination and initial seedling development patterns at the $5 \mathrm{~cm}$ depth. While control and trampled plots were similarly loosened when packets of seeds were buried, only the trampled plots showed enhanced germination and development. In one specific group of seed packets, located close to a fallen treetop and within $4 \mathrm{~m}$ of the trunk of that dead tree, control and trampled seed packets showed equally high germination and enhanced seedling development, which indicates that other factors such as a local mycorrhizal distribution may be implicated (Bidartondo \& Read, 2008). Voss (1972) suggested that $E$. helleborine responds positively to disturbance. Wittig and Wittig (2008) wondered why E. helleborine, compared to so many other terrestrial species, has been able to colonize human habitats successfully in Central Europe. Perhaps soil compaction alters habitat to its favor as it has similarly colonized ruderal habitats across North America since it was introduced in the 19th century. Anecdotal evidence that this weedy orchid prefers disturbed ground beside trails may not be ill founded.

Our trampling studies have revealed that the fungivorous nematode population decreases with trampling in a variety of soils and forested habitats and 
especially so in research trails where this effect has been noted for two years. Disturbance which loosened soil (burying seed packets or the insertion of probes as in our 2006 study) did not have the same impact on the nematode community or on the germination of $E$. helleborine as did disturbance by compaction. The data indicate that trampling somehow disrupts the nematode- fungus interaction in the compacted soil and that this disturbance may be reflected in the fungal community, in particular the ectomycorrhizal community, where orchid seed germination outcomes are determined. This is especially interesting in the case of E. helleborine which is known to be mycorrhizal with ectomycorrhizae associated with trees (Selosse et al., 2004). Trampling could somehow be modifying the fungal flora, possibly leading to the predominance of some fungi over others (Brussaard et al., 2001; Bidartondo \& Read, 2008). Certain fungi in trampled soil could become less palatable to nematodes or less accessible as a food source, which could happen if the fungal cell walls became thickened and less penetrable by nematode feeding stylets. Additionally, nematodes might not reproduce in trampled areas or they could migrate elsewhere if food choices became limited. It is also possible that the soil bacterial community is changed because of trampling and this impacts differentially upon the fungal assemblage or the nematode community, but this has not been investigated. We did observe a spike in opportunistic bacterivorous nematode numbers after trampling, so this avenue of investigation cannot be discounted (Light \& MacConaill, 2007).

There is a growing body of concern expressed by plant and animal conservationists that there may be an overemphasis on single species and rare species conservation with a paucity of understanding of ecosystem components and functioning for even common species (Jiguet \& Juilliard, 2006; Whiteley et al., 2006; Gaston \& Fuller, 2007). There is a real need for understanding of both rare and common species and their role within their respective communities. Protection of a few areas may not be sufficient to support what are now common species. Gaston and Fuller (2007) have argued that we need to pay more attention to common species. This good advice should be heeded by those of us tasked with orchid conservation.
ACKNOWLEDGMENTS. The authors thank the National Capital Commission for permission to do research in Gatineau Park.

\section{LiteRATURE CITED}

Bidartondo, M. I. \& D. J. Read. 2008. Fungal specificity bottlenecks during orchid germination and development. Molec. Ecol. 17: 3707-3716.

Brussaard, L., T. W. Kuyper, \& R. G. M. de Goede. 2001. On the relationships between nematodes, mycorrhizal fungi and plants: functional composition of species and plant performance. Pl. Soil 232: 155-165.

Dixon, K. \& G. Backhouse. 2007. Minutes of Meeting of Australian Region Orchid Specialist Group. Third International Orchid Conservation Congress, San José, Costa Rica. 19 March 2007. www.orchidconservation. org/OSG/Docs/GM0703.doc

Gaston, K. J. \& R. A. Fuller. 2007. Commonness, population depletion and conservation biology. Trends Ecol. Evol. 23: 14-19.

Johansen, B. \& S. Fredericksen. 2002. Orchid flowers: evolution and molecular development. Pp. 206-219 in: Q. C. B. Cronk, R. M. Bateman \& J. A. Hawkins (eds.), Developmental genetics and plant evolution. CRC Press, Florida, USA.

Jiguet, F. \& R. Julliard. 2006. Inferences from common species communities for selecting conservation areas. Biod. Cons. 15: 799-815.

Light, M. H. S. \& M. MacConaill. 2002a. Climatic influences on flowering and fruiting of Cypripedium parviflorum var. pubescens. Pp. 85-97 in: P. Kindlmann, J. H. Willems, \& D. F. Whigham (eds.), Trends and fluctuations and underlying mechanisms in terrestrial orchid populations. Backhuys Publishers, Leiden, The Netherlands.

Light, M. H. S. \& M. MacConaill. 2002b. Behaviour of a population of Cypripedium parviflorum Salisb. var. pubescens (Willd.) Knight in Gatineau Park, Québec, Canada - a 12-year overview. Eurorchis 14: 17-22.

Light, M. H. S. \& M. MacConaill. 2006a. Appearance and disappearance of a weedy orchid. Fol. Geobot. 41: 77-93.

Light, M. H. S. \& M. MacConaill. 2006b. Long-term studies: a case for orchid species survival. Selbyana 26: 174-188.

Light, M. H. S. \& M. MacConaill. 2007. Effects of trampling on a terrestrial orchid environment. Lankesteriana 7: 294-298.

Light, M. H. S. \& M. MacConaill. 2008. Watch your step. Orchids 77: 128-133.

Nantel, P. \& D. Cantin. 1998. La situation du cypripèdeoeuf-de-passereau (Cypripedium passerinum) au 
Québec. Direction de la conservation et du patrimoine écologique, ministère de l'Environnement du Québec, Saint-Laurent Vision 2000.

Neher, D. A. 2001. Role of nematodes in soil health and their use as indicators. J. Nemat. 33: 161-168.

Schlueter, P. M. \& F. P. Schiestl, 2008. Molecular mechanisms of floral mimicry in orchids. Trends Pl. S. 13: $228-235$.

Selosse, M.-A., A. Faccio, G. Scappaticci, \& P. Bonfante. 2004. Chlorophyllous and achlorophyllous specimens of Epipactis microphylla (Neottieae, Orchidaceae) are associated with ectomycorrhizal septomycetes, including truffles. Microbial Ecol. 47: 416-426.

Sokal, R. R. \& F. J. Rohlf. 1981. Biometry. 2nd edition. W.
H. Freeman and Company, New York, USA.

Somerville, C. \& M. Koormeet. 2002. A fortunate choice: the history of Arabidopsis as a model plant. Nat. Rev. Gen. 3: 883-889.

Voss, E. G. 1972. Michigan flora. Part I. Gymnosperms and monocots. Cranbrook Institute of Science and University of Michigan Herbarium, Ann Arbor, Michigan, USA.

Whiteley, A. R., P. Spruell, \& F. W. Allendorf. 2006. Can common species provide valuable information for conservation? Molec. Ecol. 15: 2767-2786.

Wittig, R. \& M. Wittig. 2007. Epipactis helleborine (L.) Crantz - the first (semi) ruderal orchid species of Central Europe. Feddes Repert. 118: 46-50. 